\title{
Penerapan penilaian autentik dalam Kurikulum 2013 pada pembelajaran Pendidikan Pancasila dan Kewarganegaraan
}

\author{
Dasmalinda ${ }^{a}$, Hasrul ${ }^{b}$, \\ a,b Program Magister Pendidikan Pancasila dan Kewarganegaraan, Fakultas IImu Sosial, Universitas Negeri \\ Padang, Padang, Indonesia
}

\begin{abstract}
ABSTRAK
Dalam pelaksanaan penilaian autentik seorang guru masih banyak mengalami kendala terutama dalam penyusunan instrumen dan pengklasifikasian domainnya. Tujuan penelitian ini adalah untuk menganalisis pelaksanaan penilaian autentik berdasarkan kurikulum 2013 dalam pembelajaran PPKn. Jenis penelitian ini adalah metode campuran (Mixed Methods) dengan pendekatan Sequential Exploratory Design. Informan dalam penelitian ini adalah seluruh guru PPKn SMKN 1 solok yang berjumlah 5 orang. Teknik pengumpulan data menggunakan observasi, wawancara, dan dokumentasi. Teknik analisis data menggunakan reduksi data, penyajian data dan verifikasi. Hasil penelitian mengambarkan bahwa, umumnya guru SMKN 1 Solok belum menggunakan instrumen penilaian autentik untuk mengukur hasil belajar dan sikap peserta didik. Harapan penelitian ini dalam pelaksanaan penilaian autentik guru mampu melaksanakan sesuai dengan kurikulum 2013.
\end{abstract}

Sejarah Artikel

Diterima :

Disetujui:

Kata kunci:

Kurikulum 2013,

penilaian autentik, PPKn

\section{Keywords:}

Curriculum 2013,

authentic assessment, purpose of this study is to analyze the implementation of authentic assessment based on the 2013 curriculum in learning PPKn. This type of research uses a mixed-method with the sequential exploratory design approach. The informants in this study were all five students of SMKN 1 Solok, with five people. Data collection techniques using observation, interviews, and documentation. Data analysis techniques using data reduction, data presentation, and verification. The results of the study illustrate that, generally, SMK 1 Solok teachers have not used authentic assessment instruments to measure student learning outcomes and attitudes. The expectation of this research in the implementation of authentic teacher assessment can carry out under the 2013 curriculum.

\section{Pendahuluan}

Penilaian pembelajaran Pendidikan Pancasila dan Kewarganegaraan memiliki keunikan tersendiri dibanding mata pelajaran lainnya. Keunikan tersebut diantaranya adalah aspek sikap yang lebih menonjol. Penilaian merupakan bagian yang tidak dapat dipisahkan dari proses pembelajaran. Penilaian menjadi salah satu bagian untuk mengukur keberhasilan pencapaian siswa dalam pembelajaran. Dengan kata lain penilaian digunakan sebagai bahan evaluasi dalam proses pembelajaran. Penilaian dilakukan karena berbagai alasan, semakin penting di antaranya adalah untuk memberikan indikasi sistematis kualitas siswa, sebagai bahan evaluasi bagu guru dalam memperbaiki kekurangan dalam mengajar, untuk mempertahankan standar dalam pendidikan profesional dan lebih tinggi, dan untuk memotivasi siswa sepanjang masa studi mereka (Miller et al., 2009).

Sistem penilaian yang baik mendorong guru menggunakan strategi mengajar yang lebih baik dan memotivasi bahkan "memaksa" anak untuk belajar lebih giat. Oleh karena itu untuk meningkatkan kualitas lulusan diperlukan peningkatan kualitas penilaian melalui penilaian 
autentik (Aiman, 2016). Penilaian autentik (authentic assessment) adalah pengukuran yang bermakna secara signifikan atas hasil belajar peserta didik untuk ranah sikap, keterampilan, dan pengetahuan. Penilaian autentik merupakan pengembangan kompetensi peserta didik secara lebih komprehensif dan objektif sampai menyelesaikan program pendidikannya (Wuryani \& Irham, 2014). Bentuk penilaian autentik menghendaki peserta didik mampu menampilkan sikap, menggunakan pengetahuan dan keterampilan yang diperoleh dari pembelajaran dan dapat menerapkannya dalam situasi yang sesungguhnya dan dapat memberikan gambaran perkembangan belajar siswa (Kunandar, 2013; Mansyur et al., 2015).

Penilaian hasil belajar yang dilakukan oleh guru cenderung hanya dari segi pengetahuan saja. Tidak dimungkiri bahwa penilaian dalam segi pengetahuan terkadang mengabaikan aspek lain yang juga tak kalah penting, aspek afektif dan psikomotor. Guru mengukur keberhasilan belajar siswa dengan tes tertulis, untuk mengukur sejauh mana siswa memahami materi yang sudah diajarkan oleh guru. Sehingga terlihat, pencapaian kompetensi pengetahuan dari siswa adalah paling utama. Padahal penilaian harus dilakukan secara komprehensif agar ketercapaian tujuan pendidikan bisa di ukur.

Berdasarkan penelitian terdahulu menurut penelitian (Zuhera et al., 2017), ada beberapa kendala yang dihadapi guru dalam pelaksanaan penilaian autentik antara lain: waktu yang sangat sedikit, jumlah siswa yang sangat banyak dalam satu kelas dan banyaknya indikator yang harus dinilai membuat guru kesulitan dalam pengisiannya (Mahmud, 2014). Sehingga penilaian Kompetensi sikap tidak terlaksana sesuai dengan instrumen yang ada. Begitu juga dengan penilaian pengetahuan dan penilaian keterampilan guru masih banyak yang tidak melakukan penilaian sesuai dengan instrumen yang ada dengan alasan belum meratanya pelatihan tentang implementasi kurikulum 2013, pengelolaan waktu yang sangat minim, kurang lengkapnya jenis penilaian yang digunakan dan belum terbiasanya menyusun rubrik penilaian, yang sangat besar sekali kendalanya adalah ketersediaan buku yang sangat terbatas (Abdullah, 2016).

Hasil penelitian Sya'idah et al. (2016), guru PAI di SMA Negeri 53 Jakarta tidak optimal dalam melaksanakan penilaian autentik. Dikarenakan, peneliti tidak menemukan instrumen penilaian non-tes yang digunakan oleh guru, namun untuk instrumen penilaian tes ditemukan oleh peneliti berupa soal-soal. Seharusnya guru menyadari bahwa dengan menggunakan instrumen penilaian akan menghasilkan informasi mengenai tingkat penguasaan peserta didik yang akurat dan terpercaya.

Hasil Penelitian Ruslan et al. (Ruslan et al., 2016), penilaian autentik merujuk pada situasi atau konteks dunia nyata, yang memerlukan berbagai macam pendekatan untuk memecahkan masalah yang memberikan kemungkinan bahwa satu masalah bisa mempunyai lebih dari satu macam pemecahan. Penilaian ini mampu menggambarkan peningkatan hasil belajar peserta didik, baik dalam rangka mengobservasi, menalar, mencoba, dan membangun jejaring. Penilaian autentik dilakukan oleh guru dalam bentuk penilaian kelas melalui penilaian kinerja, portofolio, produk, proyek, tertulis, dan penilaian diri. Penilaian yang autentik dilakukan secara terintegrasi dengan proses pembelajaran. Penilaian ini dilakukan secara terus menerus selama kegiatan pembelajaran berlangsung dan meliputi seluruh aspek domain penilaian. Penilaian semacam ini cenderung berfokus pada tugas-tugas kompleks atau kontekstual bagi peserta didik, yang memungkinkan mereka secara nyata menunjukkan kompetensi atau keterampilan yang dimilikinya.

Dalam menerapkan penilaian pada proses pembelajaran Kurikulum 2013 dapat dikatakan masih banyak kendala yang dialami oleh guru-guru di 3 SD di Kabupaten Pidie (Ruslan et al., 2016). Kendala terbesar guru pada Kurikulum 2013 adalah guru merasa terbebani dengan adanya penilaian format penilaian yang terlalu banyak sehingga membuat guru terbebani dalam 
Dasmalinda, Hasrul. Penerapan penilaian autentik dalam Kurikulum 2013 pada pembelajaran Pendidikan Pancasila dan Kewarganegaraan

melakukan penilaian dan guru harus menilai secara detail dalam proses pembelajaran. Guru masih kebingungan dalam proses penilaian yang dapat memberikan gambaran sikap, pengetahuan dan keterampilan yang dikaitkan dengan kehidupan nyata mereka di luar sekolah. Guru juga terkendala dengan waktu dan terlalu ribet dengan rubrik, jika nilai yang diambil ketiga aspek pada setiap pembelajaran kenapa harus sebanyak itu format penilaian. Padahal format penilaiannya bisa di buat lebih spesifik. Penilaian yang terlalu banyak sehingga menghabiskan waktu dalam memilah aspek yang mengakibatkan pembelajaran dalam satu hari itu tidak semuanya tuntas dilaksanakan. Pada saat guru mulai mengajar di situlah guru tersebut langsung harus menilai setiap siswa karena banyaknya anak tidak mungkin guru bisa mengingat terus semuanya, dan penilaian juga dilakukan sampai akhir pembelajaran. Kemudian item penilaian pun terlalu rumit per sub tema dan tema. Pada aspek penilaian sikap juga dirasakan sangat sulit karena guru tidak mungkin bisa memantau sekian banyak anak didik. Bukan hanya pada penilaian sehari-hari siswa saja yang membuat guru merasa sangat terbebani, guru juga merasa berat karena harus menjumlahkan setiap nilai yang diperoleh siswa secara keseluruhan lalu mendeskripsikan hasil nilai yang didapat tersebut per mata pelajaran. Padahal hasil yang diperoleh sehari-hari tidak semuanya dimasukkan kedalam rapor. Banyak orang tua siswa kurang puas dengan hasil penilaian yang berbentuk deskripsi, sehingga guru harus selalu menjelaskan setiap kalimat yang dideskripsikan, dan menjelaskan berapa nilai yang diperoleh oleh siswa. Hambatan yang dialami guru dalam merancang dan melaksanakan penilaian autentik adalah penyusunan soal yang banyak, format yang terlalu rumit membuat guru kewalahan dalam melakukan penilaian kepada setiap peserta didik. Selain itu juga terdapat kendala lain yakni waktu untuk menyusun dan melaksanakan penilaian autentik sangat terbatas. Sehingga guru kerepotan dan kurang maksimal dalam menyusun dan melaksanakan penilaian autentik.

Setiadi (2016), dalam penelitiannya penilaian autentik terutama penilaian sikap dapat dilakukan dengan beberapa cara yakni observasi perilaku, penilaian diri, penilaian antar teman, membuat jurnal dan penggunaan skala sikap. Walaupun pengukuran sikap dapat dilakukan dengan berbagai cara, namun tidak berarti semua teknik itu harus dilaksanakan oleh guru-guru di sekolah. Dari hasil Focus Group Discussion (FGD) didapatkan informasi bahwa guru-guru memahaminya untuk mengukur kompetensi sikap, mereka harus melaksanakan semua teknik yang disebutkan di atas. Karena waktunya tidak cukup dan siswanya banyak sehingga banyak guru-guru yang tidak melaksanakan penilaian sikap. Dari hasil temuan FGD ternyata sedikit sekali guru-guru yang melakukan penilaian kompetensi sikap baik dengan lembar observasi, lembar penilaian diri, penilaian antar teman, dan membuat jurnal. Banyak guru yang mengeluh kesulitan dalam melakukan penilaian sikap, terutama karena mereka tidak ada waktu, dan terlalu banyak siswa yang harus dinilai. Kondisi lapangan tersebut sama dengan fakta yang telah dikemukakan oleh Markle \& O'Banion (2014), bahwa masih sangat sedikit guru yang melakukan penilaian efektif dengan baik di lapangan.

Hal serupa juga dialami oleh beberapa sekolah yang telah melakukan kurikulum 2013 di Kota Solok, terutama SMKN 1 Kota Solok yang mana sekolah ini telah menerapkan kurikulum 2013 sejak 6 tahun yang lalu. Hasil penelitian menunjukkan masih banyak guru yang belum mengunakan instrumen penilaian autentik yang komprehensif, pada umumnya mereka hanya melakukan penilaian pengetahuan yang instrumennya masih menggunakan instrumen KTSP. Sedangkan untuk penilaian keterampilan disesuaikan saja dengan nilai pengetahuan. Penilaian yang dilakukan guru masih cenderung subjektif dan tidak mengacu kepada indikator penilaian yang benar.

\section{Metode}

Peneliti ini menggunakan metode campuran (mixed methods) dengan pendekatan sequential exploratory design. Metode ini pada tahap awal menggunakan metode kualitatif dan 
selanjutnya menggunakan metode kuantitatif. Pada penelitian ini yang lebih dominan adalah metode tahap pertama, yaitu metode kualitatif tipe deskriptif (Sugiyono, 2012). Peneliti mencoba menyajikan data, menganalisis, menginterprestasikan dan mengungkapkan semua fenomena, gejela, kejadian secara apa adanya dalam bentuk keterangan-keterangan yang terjadi pada tempat yang diteliti. Penelitian kualitatif merupakan penelitian yang menghasilkan prosedur analisis yang tidak menggunakan prosedur analisis statistik atau cara kuantifikasi lainya ,karena sesuai dengan masalah yang diteliti. Pada metode kualitatif capaian informasi tentang sesuatu yang baru sedikit diketahui, maka dirinci dengan kompleks oleh metode kuantitatif.

Lokasi penelitian yaitu di SMKN 1 Kota Solok dengan informan yaitu 5 orang guru PPKn dengan melakukan wawancara kepada 5 orang guru tersebut dan juga melakukan angket kuisioner sesuai dengan data yang dibutuhkan. Teknik pengumpulan data yaitu melakukan beberapa prosedur yaitu pertama, observasi peneliti langsung turun kelapangan untuk mengamati proses pembelajaran dan penilaian. Kedua, wawancara dengan para informan dan Ketiga, studi dokumentasi dengan menganalisis Rencana Pelaksanaan Pembelajaran (RPP) yang susun oleh guru PPKn. Uji keabsahan data menggunakan strategi validitas untuk keakuratan hasil penelitian dan teknik triangulasi. Analisis data dilakukan secara sistematis dari hasil wawancara, catatan lapangan dan dokumentasi dengan cara mengorganisasikan data ke dalam kategori, menjabarkan ke unit-unit, melakukan sintesis dan menyusun ke dalam pola sehingga membuat suatu kesimpulan.

\section{Hasil dan Pembahasan}

\section{Penilaian sikap (afektif)}

Pada domain afektif, harus dilakukan melalui penilaian autentik. Ranah afektif merupakan ranah yang paling kompleks karena terdapat dalam kehidupan psikologis siswa dan merefleksikan keyakinan, sikap, kesan, keinginan, perasaan dan minat siswa. Allen dan Friedman (2010) mengatakan pada umumnya orang mengabaikan domain afektif ini karena domain afektif belum terkonseptualisasikan secara jelas, bersifat sangat individual dan sulit untuk dinilai. Ditambah dengan konsep nilai-nilai itu sendiri yang bersifat abstrak sehingga membuat penilaian afektif menjadi hal yang cukup menyulitkan dilakukan oleh guru. Di samping itu penerapan tes terstandar serta penerapannya yang di seluruh bidang studi menyebabkan perhatian pada domain ini menjadi semakin kurang.

Di sisi lain Popham (1999) dan Beane (1993) berpendapat bahwa domain afektif merupakan domain yang sangat penting dalam pendidikan. Keberhasilan siswa dalam mempelajari pengetahuan yang berada pada domain kognitif sangat ditentukan oleh perkembangan siswa di domain afektif. Di samping itu banyak bukti menunjukkan bahwa banyak orang yang tidak begitu pintar dalam hal akademis namun menjadi orang yang sukses dalam kehidupannya, karena afeksi yang baik yang ditunjukkan dalam sikap dan perilakunya. Oleh karena itu, mereka berpendapat bahwa pengembangan ranah afektif dalam pendidikan sangat diperlukan dan tidak boleh diabaikan sehingga kebiasaan selama ini yang mendewakan aspek kognitif harus hilangkan karena pada hakikatnya bagaimanapun penilaian harus dalam koridor yang seimbang terhadap aspek afektif, kognitif, dan psikomotor.

Menurut Kunandar (2013, hal. 61), penilaian hasil belajar dapat dilakukan secara (1) terpadu yang berarti penilaian mencakup ranah sikap, pengetahuan, dan keterampilan secara terintegrasi dan merupakan komponen yang tak terpisahkan dari kegiatan pembelajaran. (2) Menyeluruh dan berkesinambungan, yang berarti penilaian mencakup ranah sikap, pengetahuan, dan keterampilan dengan menggunakan berbagai teknik penilaian yang sesuai, untuk memantau dan menilai perkembangan kemampuan peserta didik. Oleh karena itu, terlepas dari kurikulum yang 
Dasmalinda, Hasrul. Penerapan penilaian autentik dalam Kurikulum 2013 pada pembelajaran Pendidikan Pancasila dan Kewarganegaraan

diimplementasikan di satuan pendidikan penilaian harus dilakukan pada ranah sikap, pengetahuan, dan keterampilan. Berdasarkan pendapat Kunandar di atas, terlihat bahwa idealnya dalam aspek penilaian guru harus mampu menyeimbangkan ketiga aspek yang menjadi fokus dalam penilaian. Hal ini karena ketiganya mempunyai makna dan urgensinya masing-masing sehingga menuntut guru untuk lebih memperhatikan lagi ketiga aspek ini dalam melaksanakan penilaian sebagai bahan evaluasi terhadap siswa di sekolah.

Penilaian sikap yang utama dilakukan dengan menggunakan teknik observasi selama periode satu semester oleh guru mata pelajaran (selama proses pembelajaran pada jam pelajaran), guru bimbingan konseling (BK), dan wali kelas (selama peserta didik di luar jam pelajaran) yang ditulis dalam buku jurnal (yang selanjutnya disebut jurnal), yang mencakup catatan anekdot (anecdotal record), catatan kejadian tertentu (incidental record), dan informasi lain yang valid dan relevan. Jurnal tidak hanya didasarkan pada apa yang dilihat langsung oleh guru, wali kelas, dan guru BK, tetapi juga informasi lain yang relevan dan valid yang diterima dari berbagai sumber. Penilaian sikap oleh guru dapat diperkuat dengan penilaian diri dan penilaian antar teman. Teknik ini dapat dilakukan dalam rangka pembinaan dan pembentukan karakter siswa, yang hasilnya dapat dijadikan sebagai salah satu data konfirmasi dari hasil penilaian sikap oleh pendidik. Selanjutnya, wali kelas mengumpulkan data/informasi dari hasil penilaian sikap yang dilakukan oleh guru mata pelajaran, guru BK, dan/atau penilaian diri dan antar teman kemudian merangkumnya menjadi deskripsi (bukan angka atau predikat) yang bagaimana mengambarkan perilaku siswa selama berada di lingkungan sekolah.

Fakta di lapangan menunjukkan bahwa penilaian sikap sudah dilakukan pada pembelajaran PPKn di SMKN 1 Solok. Namun pelaksanaannya belum maksimal. Hal ini karena penilaian sikap masih sangat subjektif. Penilaian sikap pada umumnya diambil dari kehadiran siswa, kalau siswa rajin datang otomatis perilakunya baik, dan akan mendapatkan nilai sikap B, sebaliknya kalau siswa malas dan sering tidak buat tugas nilai sikapnya C. Format dan indikatornya bukan tidak ada. Namun terlalu banyak indikator yang harus di isi membuat guru tidak melakukan penilaian sikap berdasarkan indikator yang ada. Hal ini menunjukkan bahwa guru belum betul-betul memahami esensi dari penilaian pada aspek ini. Permasalahan ini tentu sangat serius. Sebagaimana yang digambarkan Popham (1999) bahwa penilaian afektif sangat penting dalam menggambarkan karakter siswa sehingga seharusnya guru tidak boleh asal-asalan dalam melakukan penilaian. Oleh karena itu penting seorang guru memperhatikan betul-betul penilaian afektif ini agar bisa memberikan gambaran yang jelas bagaimana perkembangan sikap siswa di sekolah sehingga dapat diketahui hal yang harus di perbaiki.

\section{Penilaian pengetahuan (kognitif)}

Kognitif merupakan domain yang paling dikenal dan paling sering digunakan dalam pendidikan. Penilaian pengetahuan dilakukan tidak semata-mata untuk mengetahui apakah peserta didik telah mencapai ketuntasan belajar (mastery learning), tetapi penilaian juga ditujukan untuk mengidentifikasi kelemahan dan kekuatan (diagnostic) proses pembelajaran. Untuk itu, pemberian umpan balik (feedback) kepada peserta didik dan guru merupakan hal yang sangat penting, sehingga hasil penilaian dapat segera digunakan untuk perbaikan mutu pembelajaran. Hasil penilaian pengetahuan dinyatakan dalam bentuk angka rentang 1-100.

Berbagai teknik penilaian dapat digunakan pada penilaian pengetahuan sesuai dengan karakteristik masing-masing Kompetensi Dasar (KD). Meskipun teknik yang biasa digunakan adalah tes lisan, tes tertulis, dan penugasan, namun tidak menutup kemungkinan digunakan teknik lain yang sesuai dengan tujuan pembelajaran. Selain itu dapat pula digunakan portofolio sebagai masukan dalam merencanakan remedial dan pengayaan. 
Taksonomi atau pengelompokan kemampuan manusia atas enam tingkatan kemampuan yang bersifat hierarkis yaitu mulai dari yang paling sederhana dari Bloom yang direvisi oleh Anderson dan Krathwol (2010). Dalam hal ini penulis mengimplikasikan enam kemampuan guru PPKn di SMKN 1 Solok sesuai dengan kriteria taksonomi bloom sebagai berikut:

Tabel 1

Taksonomi pengelompokan kemampuan guru PPKn di SMKN 1 Solok

\begin{tabular}{|c|c|c|c|c|}
\hline No & Substansi & Deskripsi & $\begin{array}{l}\text { Faktual di SMKN } 1 \\
\text { Solok } \\
\end{array}$ & Keterangan \\
\hline 1 & Remember & $\begin{array}{l}\text { Kemampuan mengambil kembali } \\
\text { pengetahuan yang berasal dari memori } \\
\text { jangka panjang }\end{array}$ & $80 \%$ & Terlaksana \\
\hline 2 & Understand & $\begin{array}{l}\text { Kemampuan untuk membangun } \\
\text { pemahaman atau makna dari pesan-pesan } \\
\text { yang diterima dalam pembelajaran }\end{array}$ & $85 \%$ & Terlaksana \\
\hline 3 & Apply & $\begin{array}{l}\text { Kemampuan untuk menggunakan prosedur } \\
\text { tertentu pada keadaan yang ditentukan }\end{array}$ & $75 \%$ & Terlaksana \\
\hline 4 & Analyze & $\begin{array}{l}\text { Kemampuan untuk memecah masalah } \\
\text { berdasarkan elemennya dan melihat } \\
\text { keterkaitan masing- masing elemen }\end{array}$ & $80 \%$ & Terlaksana \\
\hline 5 & Evaluate & $\begin{array}{l}\text { Kemampuan untuk menilai atau } \\
\text { mempertimbangkan sesuatu berdasarkan } \\
\text { kriteria dan standar yang ada }\end{array}$ & $85 \%$ & Terlaksana \\
\hline 6 & Create & $\begin{array}{l}\text { Kemampuan tertinggi dalam mengonstruksi } \\
\text { sesuatu yang baru berdasarkan elemen- } \\
\text { elemen yang ada. }\end{array}$ & $70 \%$ & Terlaksana \\
\hline
\end{tabular}

Sumber: data hasil penelitian, 2019.

Dari tabel di atas penilaian pengetahuan di SMKN 1 Solok sudah terlaksana dengan berdasarkan total persentase yaitu 79,2 \% yang berarti penilaian pengetahuan baik namun ada beberapa indikator dalam penilaian kurikulum 2013 yang belum terlaksana secara keseluruhan.

\section{Penilaian Keterampilan (Psikomotor)}

Pelaksanaan penilaian yang dilakukan oleh guru PPKn pada umumnya belum menggunakan teknik penilaian yang sesuai dengan kurikulum 2013. Guru belum melakukan penilaian autentik. Di sisi lain penilaian yang dilakukan guru umumnya masih fokus kepada penilaian pengetahuan, sementara penilaian sikap dan keterampilan sering terabaikan. Penilaian sikap dan keterampilan yang diberikan guru cenderung subjektif, hanya dengan melihat kehadiran peserta didik. Penilaian autentik seharusnya bisa dilakukan melalui penilaian kinerja, penilaian diri, penilaian proyek, penilaian portofolio, dan penilaian tertulis untuk semua domain penilaian. Namun realitanya, di SMKN 1 Solok penilaian autentik ke tiga domain ini belum terlaksana. Sementara ketiga domain ini sangat urgen dalam mengukur kompetensi peserta didik.

Temuan di lapangan menunjukkan bahwa penilaian pada aspek keterampilan dilakukan dengan cara menyesuaikan nilai keterampilan dengan nilai pengetahuan. Jika nilai pengetahuan baik maka secara otomatis nilai keterampilan juga baik. Sebaliknya jika nilai pengetahuan buruk maka nilai keterampilan juga buruk pada umumnya ditemukan pada guru-guru Muatan Nasional dan Kewilayahan. Sedangkan untuk guru-guru produktif sebagian mereka sudah melaksanakan penilaian keterampilan karena setiap akhir semester mereka harus menyelesaikan suatu proyek,

Berdasarkan paparan temuan penelitian dan kajian teoretis di atas terlihat masih adanya kesenjangan dalam penilaian. Penilaian sikap dan keterampilan masih cenderung diabaikan oleh guru sendiri. Padahal ketiga aspek ini sangat penting dan berkaitan satu sama lain. Penilaian 
Dasmalinda, Hasrul. Penerapan penilaian autentik dalam Kurikulum 2013 pada pembelajaran Pendidikan Pancasila dan Kewarganegaraan

autentik harus dilakukan oleh guru untuk mengukur kompetensi peserta didik dalam segala aspek, namun hal ini tidak dilakukan.

Kendala-Kendala dalam Pelaksanaan Penilaian Autentik

Dalam pelaksanaannya, penilaian autentik juga menemui banyak hambatan-hambatan. Pierre dan Oughton (2007) mengemukakan bahwa pembelajaran dan penilaian di ranah afektif adalah sesuatu yang mutlak diperlukan dalam dunia pendidikan, akan tetapi kenyataannya domain ini seperti daerah tidak bertuan yang jarang diteliti dan dikaji. Oleh karena itu pendidik harus lebih menaruh perhatian terhadap bagaimana domain ini diperlakukan di sekolah termasuk dalam menilainya.

Penelitian tentang penilaian afektif dan psikomotor juga urgen untuk dilaksanakan karena kecenderungan yang ada di sekolah adalah keengganan guru PPKn untuk melaksanakan penilaian afektif (Adisusilo, 2012). Keengganan itu pada umumnya didasari oleh sulitnya dan susahnya mengembangkan instrumen penilaian yang akan digunakan serta kebingungan menentukan metode dan prosedur yang akan digunakan. Hal ini juga di akibatkan kurangnya pengetahuan guru dalam menyusun dan mengembangkan instrumen penilaian yang ada sehingga penilaian ini tidak terlaksana dengan baik.

Berdasarkan hasil wawancara guru mengalami kendala dalam melakukan penilaian keterampilan antara lain; keterbatasan waktu yang dimiliki oleh guru. Pada proses belajar mengajar, guru kesulitan dalam membagi waktu antara penyampaian materi, pemberian tugas dan evaluasi. Dengan keterbatasan waktu sehingga guru mengalami kesulitan dalam penilaian terutama penilaian kinerja dan proyek. Selain itu guru masih sulit membedakan antara penilaian kinerja, proyek dan portofolio penyebabnya guru masih kurang paham dalam penilaian kurikulum 2013.

Beberapa kendala yang dihadapi guru dalam pelaksanaan penilaian autentik di SMKN 1 Solok, diantaranya pertama, keterampilan guru dalam membuat instrumen penilaian masih rendah. Berdasarkan temuan di lapangan terkait dengan keterampilan guru dalam membuat instrumen, dapat di lihat dalam tabel berikut:

Tabel 2

Keterampilan Guru Dalam Membuat Instrument Penilaian

\begin{tabular}{|c|c|c|c|c|}
\hline No & Responden & Penilaian Sikap & Penilaian Pengetahuan & Penilaian Keterampilan \\
\hline 1 & Guru 1 & $\begin{array}{l}\text { Tidak membuat instrument } \\
\text { penilaian }\end{array}$ & $\begin{array}{l}\text { Tes tertulis saja, tes lisan } \\
\text { dan portofolio tidak } \\
\text { pernah }\end{array}$ & $\begin{array}{l}\text { Keterampilan hanya } \\
\text { menggunakan portofolio }\end{array}$ \\
\hline 2 & Guru 2 & $\begin{array}{l}\text { Membuat instrument dan } \\
\text { hanya menggunakan jurnal }\end{array}$ & $\begin{array}{l}\text { Tes tertulis saja, tes lisan } \\
\text { dan portofolio ada. }\end{array}$ & $\begin{array}{l}\text { Keterampilan hanya } \\
\text { menggunakan portofolio }\end{array}$ \\
\hline 3 & Guru 3 & $\begin{array}{l}\text { Membuat instrument dan } \\
\text { hanya menggunakan jurnal }\end{array}$ & $\begin{array}{l}\text { Tes tertulis saja, tes lisan } \\
\text { dan portofolio ada. }\end{array}$ & $\begin{array}{l}\text { Keterampilan hanya } \\
\text { menggunakan portofolio }\end{array}$ \\
\hline 4 & Guru 4 & $\begin{array}{l}\text { Membuat instrument dan } \\
\text { hanya menggunakan jurnal }\end{array}$ & $\begin{array}{l}\text { Tes tertulis saja, tes lisan } \\
\text { dan portofolio ada. }\end{array}$ & $\begin{array}{l}\text { Keterampilan hanya } \\
\text { menggunakan portofolio }\end{array}$ \\
\hline 5 & Guru 5 & $\begin{array}{l}\text { Tidak membuat instrument } \\
\text { penilaian }\end{array}$ & $\begin{array}{l}\text { Tes tertulis saja, tes lisan } \\
\text { dan portofolio tidak } \\
\text { pernah }\end{array}$ & $\begin{array}{l}\text { Keterampilan hanya } \\
\text { menggunakan portofolio }\end{array}$ \\
\hline
\end{tabular}

Sumber: Data hasil penelitian, 2019.

Berdasarkan data di atas guru di SMKN 1 Solok terlihat bahwa keterampilan guru dalam membuat instrumen masih rendah. Pada aspek penilaian sikap, dari lima guru yang dijadikan responden, hanya tiga orang yang bisa membuat instrumen namun selalu menggunakan 
instrumen yang sama saat melakukan penilaian sikap yakni jurnal, sedangkan dua orang responden lainnya tidak membuat instrumen penilaian.

Dari aspek pengetahuan, responden juga dominan menggunakan tes tertulis sebagai bahan evaluasi pengetahuan. Meskipun sebagian ada yang menggunakan tes lisan dan portofolio sebagai salah satu instrumen dalam melakukan penilaian pengetahuan. Sedangkan dalam aspek keterampilan, kelima responden sama-sama hanya menggunakan portofolio dalam pelaksanaan penilaian dalam pembelajaran.

Kedua, waktu yang relatif singkat, mata pelajaran PPKn hanya 2 jam pelajaran sementara beban materi cukup banyak dan jumlah siswa juga cukup banyak per kelasnya. Permasalahan waktu pelajaran, beban materi dan jumlah siswa dalam satu kelas menjadi permasalahan dan tantangan tersendiri dalam melaksanakan penilaian autentik dalam pembelajaran. Pembelajaran di SMKN 1 Solok juga mengalami hal demikian. Hal ini dapat dilihat pada tabel berikut:

Tabel 1.3 Deskripsi kendala waktu dan jumlah siswa pada tiap kelasnya

\begin{tabular}{cccccc}
\hline No & Beban Materi & \multicolumn{2}{c}{ Jumlah Siswa } & \multicolumn{2}{c}{ Waktu Pembelajaran } \\
& & Faktual & Seharusnya & Faktual & Seharusnya \\
\hline 1 & Padat & 40/Kelas & 25/Kelas & 90min/Minggu & 135min/Minggu \\
\hline
\end{tabular}

Sumber: Data hasil penelitian, 2019.

Dengan jumlah siswa yang banyak, dalam waktu pembelajaran 90 menit per minggu, pembelajaran tidak terlaksana dengan efektif sehingga Indikator Pencapaian Kompetensi (IPK) tidak tercapai sesuai tuntutan kurikulum 2013. Jumlah waktu yang terbatas dan jumlah siswa yang cukup banyak tidak memungkinkan bagi guru untuk melakukan penilaian secara efektif dan efisien. Padahal dalam aturannya, per kelas seharusnya hanya boleh di isi maksimal sampai 32 orang siswa. Sementara satu kelas di SMKN 1 Solok di isi sampai oleh 40 siswa yang tentu saja cukup menyulitkan guru melakukan penilaian. Sudah selayaknya berbagai pihak terutama pihak sekolah meninjau kembali permasalahan ini agar pelaksanaan kegiatan penilaian bisa dilakukan dengan sebaik-baiknya.

Ketiga, mindset guru yang masih menganggap bahwa penilaian merupakan syarat formalitas dan bisa diukur hanya dengan kemampuan kognitif. Pola mengajar guru masih menggunakan pola yang konservatif padahal sesuai dengan tuntutan kurikulum 2013 dan diikuti dengan perkembangan zaman mengharuskan guru untuk menerapkan pendidikan abad-21 yang mana guru hanya sebagai fasilitator dan siswa yang lebih cenderung atau dominan dalam proses pembelajaran atau student center. Pola pendidikan abad-21 memungkinkan siswa untuk mencari dan menggali sendiri pengetahuan baru yang sesuai dengan kompetensi yang ditetapkan sehingga melatih mereka memiliki kemampuan berfikir yang kritis, terampil dan mengedepankan nilai-nilai karakter sebagai yang utama

Untuk mengatasi kendala yang dihadapi guru pihak sekolah telah melakukan workshop terhadap guru-guru terutama tentang penilaian. Di samping itu adanya pengiriman guru untuk melakukan pelatihan guru terutama tentang penilaian baik di tingkat Kota maupun di tingkat Provinsi merupakan salah satu bentuk usaha yang dapat di tempuh agar aspek penilaian betulbetul bisa di pahami dan dilaksanakan dengan baik oleh guru.

Penilaian autentik sangat penting untuk diterapkan dalam implementasi kurikulum 2013 dengan memandang penilaian dan pembelajaran berorientasi pada pertumbuhan dan perkembangan peserta didik secara holistik. Penilaian autentik menuntut peserta didik mendemonstrasikan pengetahuan dan keterampilannya untuk menyelesaikan masalah nyata. Agar kompetensi yang dikuasai dapat digunakan secara bermakna dalam kehidupan, guru harus 
Dasmalinda, Hasrul. Penerapan penilaian autentik dalam Kurikulum 2013 pada pembelajaran Pendidikan Pancasila dan Kewarganegaraan

merancang masalah nyata yang bermakna dan menunjukkan kebermanfaatan ilmu pengetahuan yang dipelajari peserta didik dalam kehidupan nyata, bukan dalam dunia sekolah.

Melalui penelitian ini diharapkan dapat memberikan gambaran bagaimana pelaksanaan penilaian autentik oleh guru di sekolah sehingga berbagai pihak tak terkecuali pemerintah dapat mengambil tindakan-tindakan yang dianggap perlu dan penting demi terlaksananya penilaian autentik yang maksimal sebagai salah satu bahan evaluasi terhadap siswa di sekolah dan standar pendidikan pada umumnya.

\section{Simpulan}

Guru belum melaksanakan penilaian autentik pada mata pelajaran PPKn sesuai tuntutan kurikulum 2013. Guru hanya fokus kepada penilaian kognitif dan mengabaikan penilaian afektif dan psikomotor. Kendala bagi guru dalam melakukan penilaian yaitu kemampuan guru dalam membuat instrument penilaian masih rendah, mindset guru dalam pembuatan instrument penilaian serta keterbatasan waktu dalam perancangan dan pelaksanaan penilaian

\section{Ucapan Terima Kasih}

Ucapan terima kasih penulis sampaikan kepada pihak yang telah membantu dalam penulisan jurnal ini , terutama kepada unsur pimpinan, guru PPKn, guru BK dan guru Agama SMKN 1 Solok, yang telah memberikan informasi terkait dengan penelitian penulis. Dan terima kasih juga penulis ucapkan kepada Bapak Dr. Hasrul, M.Si. selaku pembimbing yang dengan sabarnya memberikan arahan penulisan ini.

\section{Referensi}

Abdullah. (2016). Implementasi penilaian autentik kurikulum 2013 pada pembelajaran Pendidikan Agama Islam di Madrasah Tsanawiyah Negeri 2 Palangka Raya. FITRAH:Jurnal Kajian IImu-ilmu Keislaman, 2(2), 59-82. https://doi.org/10.24952/fitrah.v2i2.470

Adisusilo, S. (2012). Pembelajaran nilai-karakter: Kontruktivisme dan VCT sebagai inovasi pendekatan pembelajaran afektif. Raja Grafindo Persada.

Aiman, U. (2016). Evaluasi pelaksanaan penilaian autentik kurikulum 2013; studi kasus di Madrasah Ibtidaiyah Negeri Tempel Sleman Yogyakarta. Jurnal Pendidikan Madrasah, 1(1), 115-122.

Allen, K. N., \& Friedman, B. (2010). Affective learning: A taxonomy for teaching social work values. Journal of Social Work Values and Ethics, 7(2), 1-12.

Anderson, L. W., \& Krathwol, D. R. (Ed.). (2010). Kerangka landasan pembelajaran, pengajaran dan asesmen. Pustaka Pelajar.

Beane, J. A. (1993). A middle school curriculum: From rhetoric to reality. National Middle School Association.

Kunandar. (2013). Penilaian autentik (Penilaian hasil belajar peserta didik berdasarkan Kurikulum 2013). Raja Grafindo Persada.

Mahmud. (2014). Kendala guru melakukan penilaian pada proses pembelajaran Kurikulum 2013 di Sekolah Dasar Gugus Delima Banda Aceh. Jurnal Pesona Dasar, 2(3), 33-44.

Mansyur, Harun, R., \& Suratno. (2015). Asesmen pembelajaran di sekolah: Panduan bagi guru dan calon guru. Pustaka Pelajar.

Markle, R., \& O'Banion, T. (2014). Assessing affective factors to improve retention and completion. Learning Abstracts, 17(11), 1-16.

Miller, M. D., Linn, R. L., \& Normnan E. Gronlund. (2009). Measurement and assessment in teaching (10 ed.). Prentice Hall.

Pierre, E., \& Oughton, J. (2007). The affective domain: Undiscovered country. College Quarterly, 10(4), 1- 
7.

http://www.eric.ed.gov/ERICWebPortal/detail?accno=EJ813766\%5Cnhttp://www.eric.ed.gov/PDFS/ EJ813766.pdf

Popham, W. J. (1999). Classroom assessment: What teachers need to know. ERIC.

Ruslan, Fauziah, T., \& Alawiyah, T. (2016). Kendala Guru dalam Menerapkan Penilaian Autentik di SD Kabupaten Pidie. Jurnal Ilmiah Mahasiswa Pendidikan Guru Sekolah Dasar, 1(1), $147-157$. https://media.neliti.com/media/publications/188254-ID-kendala-guru-dalam-menerapkanpenilaian.pdf

Setiadi, H. (2016). Pelaksanaan penilaian pada Kurikulum 2013. Jurnal Penelitian dan Evaluasi Pendidikan, 20(2), 166. https://doi.org/10.21831/pep.v20i2.7173

Sugiyono. (2012). Metode penelitian kuantitatif kualitatif dan R\&D. Alfabeta.

Sya'idah, U., Amaliyah, A., \& Ismail, Y. (2016). Kemampuan guru PAl dalam merencanakan dan melaksanakan penilaian autentik. Jurnal Online Studi Al-Qur'an, 12(2), $143-157$. https://doi.org/10.21009/jsq.012.2.01

Wuryani, W., \& Irham, M. (2014). Penilaian dalam perspektif kurikulum 2013. Insania, 19(1), 181-199.

Zuhera, Y., Habibah, S., \& Mislinawati. (2017). Kendala Guru dalam Memberikan Penilaian Terhadap Sikap Siswa dalam Proses Pembelajaran Berdasarkan Kurikulum 2013 di SD Negeri 14 Banda Aceh. IImiah Pendidikan Guru Sekolah Dasar, 2(1), 73-87. 